\title{
Aspects of Contemporary Irish Horror Cinema
}

\author{
By Seán Crosson \\ Spring 2012 Issue of KINEMA
HORROR, HURLING, AND BERTIE: ASPECTS OF CONTEMPORARY IRISH HORROR CINEMA

THIS GRAFFITI image ${ }^{(1)}$ appeared in Dublin's Ranelagh district in June 2009. In its representation of a dejected looking Bertie Aherne combined with the distinctive and unmistakable markings of a particular animal, it reflected the close association of the former Taoiseach (Irish Prime Minister) with the years of the so-called Celtic Tiger economy and the widespread disillusionment with subsequent economic decline and revelations of government mismanagement of the boom. ${ }^{(2)}$ The publication of the Report of the Special Group on Public Service Numbers and Expenditure Programmes, popularly know as 'An Bord Snip Nua', the following month marked the most bold and alarming statement of the decline of this 'Tiger' and the confirmation of the recessionary state of the Republic of Ireland. One of the more alarming recommendations of the board was the proposal to abolish Bord Scannán na hÉireann (The Irish Film Board), a proposal likely to have catastrophic consequences for the Irish film industry if implemented given its dependence on the board for financing and support. The report argued that

The Group considers that continued funding of the Irish Film Board is not affordable at this time in the context of other more pressing spending priorities. Given the scale of tax expenditure (€418m since 1993 and $€ 33 \mathrm{~m}$ in 2008 ) via the tax incentive scheme for this sector, and given the level of international competition in this market space, there is no objective economic case for subventing the Irish Film Industry (McCarthy, 18).

These reasons offered are remarkably similar to those given for the closure of the first inauguration of The Irish Film Board in October 1987 by the Pianna Fáil government returned to power earlier that year. As the then Taoiseach, Charles J. Haughey remarked in the Dáil (Irish parliament), with regard to the Board's 'failure' to recoup investments made in films funded:

the board did not succeed in developing the industry on a commercial basis. It is for that reason that the Government decided to wind down the affairs of the board and adopt the alternative strategy to develop an indigenous film industry. ${ }^{(3)}$

However, commentators at the time and subsequently were of the opinion that it was the dark subjects in Film Board funded films, often critically engaged with Irish society and government policy, that were a significant influence on the government's decision. While the editors of Cinema and Ireland suggested that 'many of the films financially aided by the Board were perceived as undermining the image of contemporary Ireland which the state itself wished to project' (Rockett, Gibbons and Hill, 1988: 274), Film West journal contributor Anthony O'Neill 'became convinced that government antipathy to indigenous films was due to what they saw as the disturbing image of Ireland coming through' (O'Neill, 1999: 16). Indeed when the Film Board was reactivated in 1993, at least one filmmaker who continued to work from the first incarnation indicated a concern that darker themes might undermine the Board's continuing existence. Director Cathal Black in 1996 noted a sense among board members and filmmakers to 'let's try and make something feel good so that we won't be accused of the kinds of things that caused the shutting down of the first Film Board' (Black, 1996: 22).

However, despite these concerns expressed by Black, films funded by the current inauguration of the Film Board have also cast a critical eye on contemporary Irish society. To suggest that these depictions contributed to the recommendations of 'An Bord Snip Nua' may be speculative, but a significant number of films funded did constitute both implicit and explicit critiques of government policy during the Celtic Tiger years. While the Celtic Tiger economy brought considerable prosperity to Ireland, and indeed has been attributed with facilitating a particular representation of Ireland in cinema, one marked by the brighter, more optimistic 
outlook of boom town Ireland in films such as About Adam (Gerry Stembridge, 2000), When Brendan Met Trudy (Kieron J. Walsh, 2000) and Goldfish Memory (Elizabeth Gill, 2003), parallel with such comedic portrayals was a darker (if sometimes still tinged with humour) strain of filmmaking, exemplified in the work of Lenny Abrahamson (Adam and Paul, 2004), Garage (2007), Prosperity (2007)), that cast a critical eye over Irish society.

While Abrahamson's work arguably represents some of the finest and most original Irish productions of the Celtic Tiger period, more generic approaches - in particular through the horror genre - also suggested unease in a time of apparent plenty. Since the mid 90s, and particularly from the early 2000s, Irish filmmakers have increasingly turned to horror as a form through which to explore aspects of Irish society, culture, history and, indeed, their representation. From Enda Hughes' The Eliminator (1996) to Stephen Bradley's Boy Eats Girl (2005), Patrick Kenny's Winter's End (2005), Billy O'Brien's Isolation (2006), Paddy Breathnach's Shrooms (2007) and Red Mist (2008), Justin O'Brien's Ghostwood (2008), Eric Courtney's Seer (2008), Conor McPherson's The Eclipse (2009), Aisling Walsh's Daisy Chain (2009), Robert Quinn's Na Cloigne (The Heads, 2010) and David Keating's The Wake Wood (2010), Irish directors have found the genre a useful means of exploring Irish locales and stories through a form familiar to audiences throughout the world. Furthermore, the Armagh based production company Midnight Pictures have specialised in making low budget horror films since the mid '90s including Zombie Genocide (1993) and Don't Look in the Attic (2005) while in 1997 the Horrorthon festival was founded by Michael Griffin and Ed King (producer of Dead Meat (2004) discussed below), to showcase new Irish and international horror cinema as well as offer rare screenings of acclaimed horror classics. ${ }^{(4)}$ Apart from feature films, horror has also been a recurring feature of short film work in this period with some of the most successful Irish shorts choosing this genre, including Emer Reynolds' White (2001), Tom Cosgrove's All God's Children (2002), Brendan Muldowney's The Ten Steps (2004), Tom Cosgrave's Rógairí (2005), Ciaran Foy's The Faeries Of Blackheath Woods (2006), and Alan Brennan's Shapes (2008). ${ }^{(5)}$

In Ireland, generic international cinematic forms (such as the horror) have provided an important means through which filmmakers have attempted to tell Irish stories while engaging international audiences. As Barry Monahan has noted 'as burgeoning national cinemas emerge into mainstream circuits of production and distribution, for reasons of economy, technology or aesthetic exploration, it is common to see degrees of address to established genres'(Monahan, 2007: 264). Indeed, part of the appeal and comedy in such films, as evidenced in Conor McMahon's Dead Meat, is how they play off familiar aspects of genre itself. As Monahan again notes 'The comedy works because in different ways the local semantics fail to sit comfortably with the generic syntax' (Ibid.).

However, in general Irish filmmakers have been less inclined until recent years to turn to that most overused and familiar of film genres, the horror. Indeed, its over familiarity may well have been a contributory factor in directors' hesitancy to adopt the horror form for their films until the mid-1990s. I want to consider in particular in this article a feature film sometimes credited, though not entirely correctly as the list above indicates, with kicking off the most recent series of horror genre films, Conor McMahon's Dead Meat (2004), a film preceded by his 2001 award-winning short The Braineater. McMahon has returned to the horror genre for his most recent film The Disturbed (2009) which was screened at the Galway Film Fleadh in 2009.(6) While Dead Meat and The Braineater are heavily indebted to previous international horror work, including films by Sam Rami, Peter Jackson, George A. Romero and Lucio Fulci, ${ }^{(7)}$ a striking feature in both is the use of elements and motifs associated with indigenous Irish culture and sport, in particular the Gaelic game of hurling, within their narratives. These films also, in common with other recent horror works, reject and critique previous touristic depictions of Ireland (an important determinant of representations of Ireland in international productions throughout the $20^{\text {th }}$ century) while providing an 'allegorical moment' both for the exploration of trauma in Ireland's distant and more recent past and a critique of Celtic Tiger Ireland itself.

Hurling is a sport with a reputed ancient pedigree and emotive charge for many Irish people, particularly since the codification of Gaelic games in the late $19^{\text {th }}$ century under the auspices of the Gaelic Athletic Association (GAA). Indeed, hurling in particular, as a game associated with such mythological figures as Cúchulainn (evoked in a scene in Dead Meat) and through the use of hurley sticks by Republican volunteers throughout the 1910s revolutionary period both as a weapon and for drilling purposes, became very closely associated with the movement for independence in Ireland. In terms of the representation of Gaelic games in 
film, particularly in international productions, depictions of hurling have also far exceeded Gaelic football, the more popular indigenous game in Ireland promoted by the GAA. ${ }^{(8)}$ A significant aspect of these international productions is how often they reveal the impact of a force termed by John Urry as 'the tourist gaze'.

The term 'the tourist gaze' was coined by Urry in his 1990 book of the same name to describe a culturally constructed manner of perceiving a place which informs tourist expectations. For Urry the tourist gaze was 'constructed through difference' and 'in relationship to its opposite, to non-tourist forms of social experience and consciousness' (Urry, 2001: 1-2). Hurling in particular would seem to have provided an authentic and 'primitive', ${ }^{(9)}$ contrast to the presumed modernity of American sports such as American football, while also apparently containing the violence so often associated with the Irish. As Rockett, Gibbons and Hill in Cinema and Ireland have noted, in terms comparable to John Urry's description of the tourist gaze, 'Whether it be rural backwardness or a marked proclivity for violence, the film-producing nations of the metropolitan centre have been able to find in Ireland a set of characteristics which stand in contrast to the assumed virtues of their own particular culture' (Rockett, Gibbons and Hill, 1988: xii). Hurling's setting in rural Ireland, and the perceived violence of the game, seemed to encapsulate both of these elements, and it is these traits that are most often emphasized and exaggerated in descriptions and depictions of the sport in American productions.

Indeed, in the first American productions to focus on hurling in the 1930s we find a recurring emphasis on the alleged violence associated with the game. In shorts such as Ted Husing's Sports Slants (episode no. 4) and Ted Husing's Sports Thrills (episode no. 5), made by the Vitaphone Corporation for Warner Bros, in 1931 and 1932, and featuring inserts on hurling, and the slightly later Pete Smith Specialty short film Hurling (David Miller, 1936), the 'oddity', 'barbarity' and 'primitiveness' of the sport of hurling are among the most emphasised features, as indicated in the promotional poster for Smith's film (fig 2).

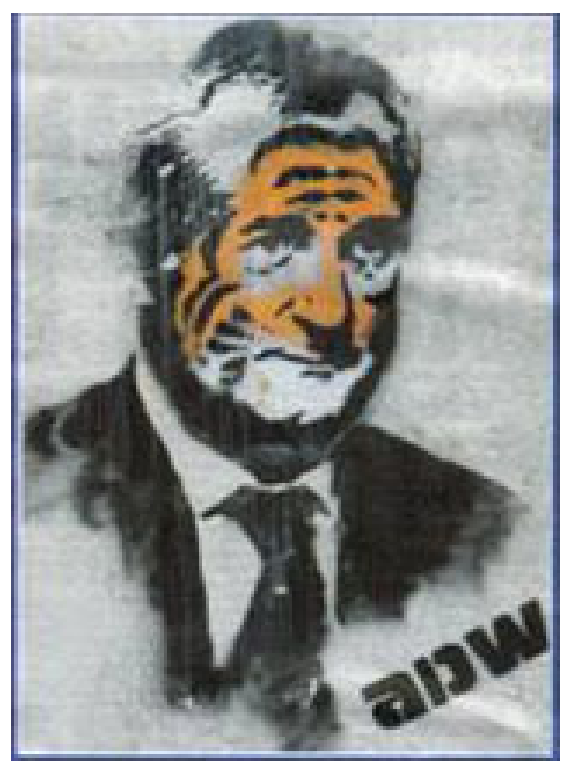

Figure 1: Fig. 1. Bertie as Celtic Tiger

This association of hurling with violence would continue in the work of the seminal Irish-American filmmaker John Ford. It is notable that in Ford's films, hurling also seems inevitably to proceed or suggest an occasion of violence. ${ }^{(10)}$ With regard to the tourist gaze, Ford's own comments indicate at least an awareness of the contribution of his work - in particular The Quiet Man (1952) - to tourism in Ireland. (11) As Joseph McBride has observed with regard to Ford's 1957 film Rising of the Moon (a film which provoked strong protests from the GAA because of its depiction of hurling players being stretchered from a game), the film

reinforces the insidious notion of Ireland as a backward island filled with lovable incompetents who haven't yet made it into the twentieth century. Ford's use of an old-fashioned train [in one sequence] with an engine built in 1886 was deliberately anachronistic, provoking a complaint from 
the director of the West Cork Railway who could not understand why Ford refused a modern train with a diesel engine. 'He'll find out when the tourists come over next summer', Ford grumbled in what [Frank S.] Nugent [the film's scriptwriter] took as an allusion to the tourist craze for jaunting carts provoked by The Quiet Man (McBride, 2001: 577-578).

Luke Gibbons has also observed how Ford's most popular Irish themed film, The Quiet Man, provided a template for the Irish tourist agency, Bord Fáilte's promotion of Ireland from its establishment in 1952, the year of The Quiet Man's release (Gibbons, 91). While we don't actually witness a game of hurling in The Quiet Man, significantly the mere mention of the game, during a dispute between the engine driver, Costello (Eric Gorman), the train guard, Molouney (Joseph O'Dea), and the stationmaster, Hugh Bailey (Web Overlander), seems to inspire violence in those discussing it.

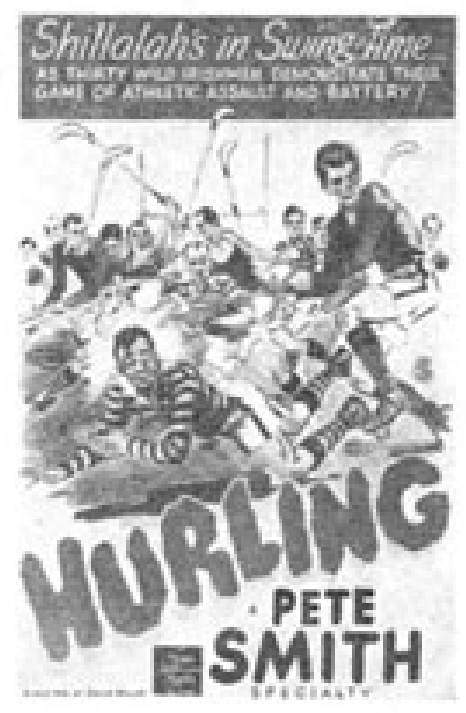

Figure 2: Fig. 2. A promotional poster for the Pete Smith Specialty Hurling (MGM 1936)

The Ireland one finds in The Quiet Man was promoted subsequently via Bord Fáilte and continues to feature in postcards such as those featured in figures $3 \mathrm{a}$ and $3 \mathrm{~b}$, available in newsagents across Ireland today, some of which draw directly on The Quiet Man film imagery:

This is a pastoral idyll, often sparsely populated by amiable and loquacious characters with a penchant for music, alcohol and recreational fighting, and a reticence towards work, a country unprepared for and challenged by the arrival of modernity. Its legacy would influence subsequent filmic representations of Ireland and aspects are found in films as diverse as Darby O'Gill and the Little People (Robert Stevenson, 1959), Finian's Rainbow (Francis Ford Coppola, 1968), Far and Away (Ron Howard, 1992), Circle of Friends (Pat O'Connor, 1995), The Matchmaker (Mark Joffe, 1997), Waking Ned (Kirk Jones, 1998), The Boys from County Clare (John Irvin, 2003) and the more recent PS I Love You (Richard LaGravenese, 2007) itself an adaptation of a novel by Bertie Aherne's daughter, Cecelia. However, what is interesting in recent Irish horror film is how often the comedic and idyllic aspects promoted in films such as these are subverted in dark and disturbing works set in often rural locales that feature little of the beauty of such earlier works. Furthermore, one senses, in the figure of the zombie as featured in McMahon's Dead Meat, a critique of the Ireland of the Celtic tiger itself and the failures and complacencies of the period.

McMahon's feature was preceded by the short The Braineater, a comic horror film in which the director's dystopian vision of rural Ireland was already apparent. The film depicts the tragic and surreal aftermath of a car accident that results in the death of a mother and father and the subsequent feralisation of their son, who survives by eating the brains of other humans and animals. When members of a local under- 12 hurling team, on their way to a match with their eccentric hurling coach, Cathal Ceaunt (Eoin Whelan) - also featured in Dead Meat - encounter this unfortunate man many years later, several are killed before 


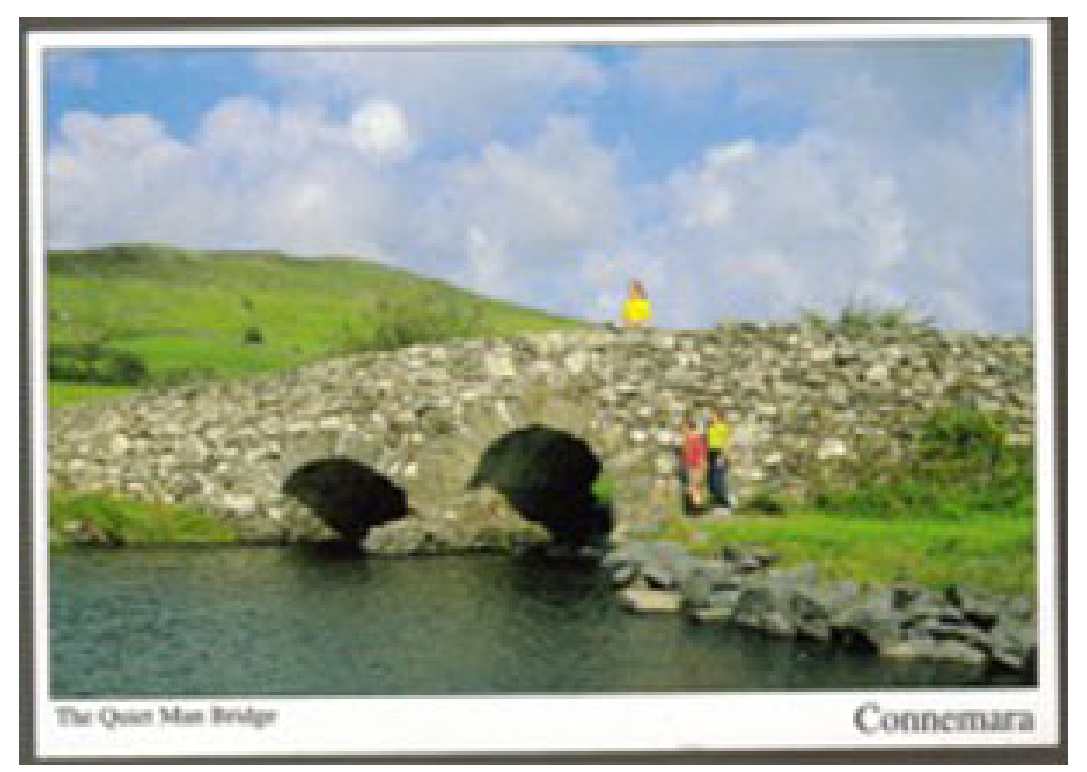

Figure 3: Fig. 3a. Contemporary postcards in Ireland

one, Cúchulainn-like, ${ }^{(12)}$ fells his assailant with his hurley stick and sliotar (the ball used in the game), ultimately decapitating him. McMahon has described the film as developing when he was at college in the Dun Laoghaire Institute of Art Design \& Technology in Dublin:

I actually wanted to make a zombie film in college, but I thought that because zombies move so slowly, that by the time they ever get their victim the film would be over. So I started thinking how could I do a zombie film, but have the character run around. This was before the time of zombies that could run. So I came up with the idea of a kid who gets hooked on brains. The whole hurling element in the Braineater is taken from an old Irish legend called Cu Culainn. In one story he kills a dog by hitting the ball through its mouth ('Interview with Conor McMahon', 2006).

Rural Ireland is often depicted in contemporary Irish horror film, as The Braineater suggests, as a place far removed from the welcoming and reassuring locale represented in tourist iconography. It is a space haunted by the hideous monsters of biological farming experiments (Billy O'Brien's Isolation), or a tortured girl's nightmares (Eric Courtney's Seer); populated by meat-eating zombies who appear without warning, attack and devour (Conor McMahon's Dead Meat); tormented by the traumatised victims of clerical abuse who, it seems until the film's surprising climax, pick off their victims one by one (in Paddy Breatnach's Shrooms); and afflicted by an apparently demonic fairy changeling child adopted by an unsuspecting immigrant English couple (Aisling Walsh's The Daisy Chain). Interestingly, in both Dead Meat and Shrooms, it is tourists who constitute the central protagonists. In Shrooms, the American students who have come to rural Ireland to experiment with drugs, are all, bar one, horrifically killed by the narrative's close - hardly a story Fáilte Ireland (the current Irish National Tourism Development Authority) would wish to promote. In Dead Meat, Spanish tourist Helena (Marián Araújo), lost in the Leitrim countryside and assisted by the local gravedigger Desmond (David Muyllaert) and trainer of the local underage hurling team, Cathal Cheunt, survives her ordeal of Leitrim's zombies (referred to by the hurling coach as 'ghowls') only to be locked up in a truck, like an animal, at the film's close. In terms of the addition of the Spanish tourist, McMahon has explained this inclusion as allowing him to create a character that other foreign viewers might be able to identify with, particularly with regard to her difficulty in understanding the strong Irish accents of characters in the film:

I thought that it might be funny to have a foreign person who didn't understand a word that the Coach character is saying. So maybe other foreign people who can't understand him could relate to her situation (Simmons, 2006). 
The characters and dialogue within the film are carefully shaped, if in exaggerated form particularly in the person of Cathal Cheunt, to evoke types familiar from Irish culture while McMahon has remarked on 'Irish humour' as 'the most unique part about the film?.(13)

However, it is the darker aspects of Ireland's distant past, that despite the obvious lack of interest indicated by the tourist Helena in several scenes, that resonates within Dead Meat. The area depicted, Desmond tells Helena at one point, is one in which Cromwell ordered the hanging of fifty men and women, while as Ruth Barton has noted

it is also a countryside dotted with ruined churches and round towers, symbols of an abandoned culture and religion. In such a landscape - and as reviewers remarked on the films release, the landscape is one of the most distinctive aspects of this film ${ }^{(14)}$ - the wandering bands of starving, homeless country people could easily be mistaken for famine victims come back to haunt the present. At the same time, McMahon's perspective is resolutely metropolitan, viewing the countryside as the locus of an unspeakable horror (Barton, 2006: 162).

Indeed, McMahon indicated in an interview after the release of Dead Meat that he had 'an idea for a zombie film set during the Irish Famine' ('Interview with Conor McMahon', 2006). Furthermore, the features Barton notes - including 'ruined churches and round towers' - which often function within the touristic vision of Ireland as markers of a heroic and glorious past, in Dead Meat are haunted by a threatening contemporary evil.

This horror Barton refers to echoes beyond the obvious living dead in Dead Meat. Indigenous Irish cinema since the 1970s has returned repeatedly to the rural, a place idolised by both tourist and sentimental nationalist in the past and present, to unearth stories of abuse and repression. Barton has also written of a series of films since the early 1990s, that develop themes apparent in work by directors such as Bob Quinn (Póitín,1978) and Joe Comerford (Reefer and the Model,1988) previously, including Broken Harvest (Maurice O'Callaghan, 1994), Korea (Cathal Black, 1995), and more recently The Magdalene Sisters (Peter Mullan, 2002). For Barton, these works 'perform a public function of enabling their viewers to work through the legacy of Irish history in its most traumatic formulations' (Barton, 2004: 131).

One might ask how horror could be relevant within this categorisation. Indeed, there has been a tendency to marginalise horror film as a lower form of entertainment, as too shocking to be considered academically or seriously. Yet as Robin Wood has noted, precisely because of this perception of horror films as mere entertainment,

full awareness stops at the level of plot, action and character, in which the most dangerous and subversive implications can disguise themselves and escape detection...this is why seemingly innocuous genre movies can be far more radical and fundamentally undermining than works of conscious social criticism (Wood, 2004: 116).

Furthermore, Adam Lowenstein, in Shocking representation: Historical Trauma, National Cinema and the Modern Horror Film, has observed how horror film has provided the 'allegorical moment' or 'a shocking collision of film, spectator, and history where registers of bodily space and historical time are disrupted, confronted, and intertwined...to produce forms of knowing not easily described by conventional delineations' (Lowenstein, 2005: 3). Bruce Kawin in his classic essay 'The Mummy's Pool' also identified this trait arguing that

Horror films function as nightmares for the individual viewer, as diagnostic eruptions for repressive societies, and as exorcistic or transcendent pagan rituals for supposedly past-pagan cultures. They can be analysed in all these ways because they represent a unique juncture of the personal, social, and mythic structures and because each of these structures has a conscious/official and unconscious/repressed dualism, whose dialectic finds expression in the act of masking (Kawin, 1999: 680).

Though 'masked' through the comic postmodern play with form and content found in McMahon's film, nonetheless both historical and more recent traumas bubble beneath the playful surface narrative of Dead Meat. As already noted, at a number of points in the film there are references to past atrocities associated 


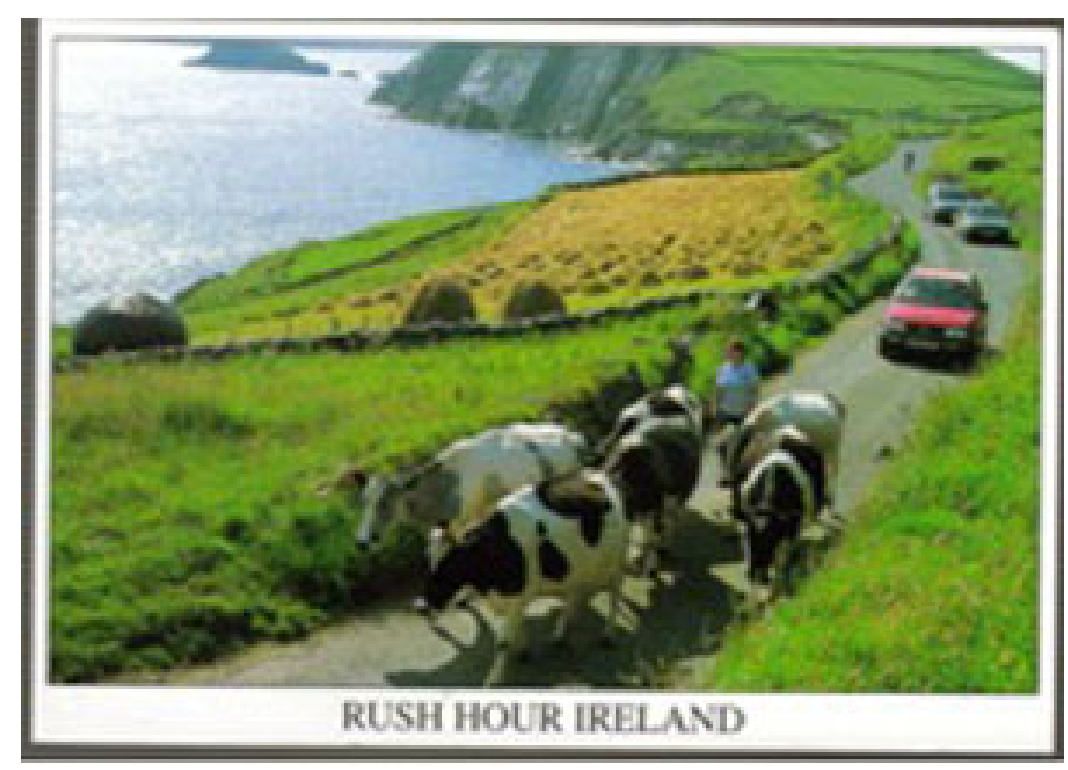

Figure 4: Fig. 3b. Contemporary postcards in Ireland

with Cromwell and the British presence in Ireland. However, Ireland's own more recent, though no less traumatic, experiences with established religion are evoked in recurring references to religious iconography in the film. In this context these features provide neither support nor comfort but appear almost entirely obsolete, apart from their use occasionally within the film as rudimentary weapons as in one scene in which Helena defends herself from a zombie (who was once her boyfriend) with the assistance of a Sacred Heart picture. One of Helena's earliest encounters with the victims of the undead is her discovery in a dilapidated cottage of the bloodied dead body of an old woman clinging to her rosary beads. The house in which she finds this woman's body contains many religious icons (figures 4 and 5), which appear repeatedly in shot providing an ineffective backdrop to the contemporary dystopian nightmare. As if to emphasise this point, in one sequence the zombie contemptuously flings some of these religious icons onto the floor of the cottage.

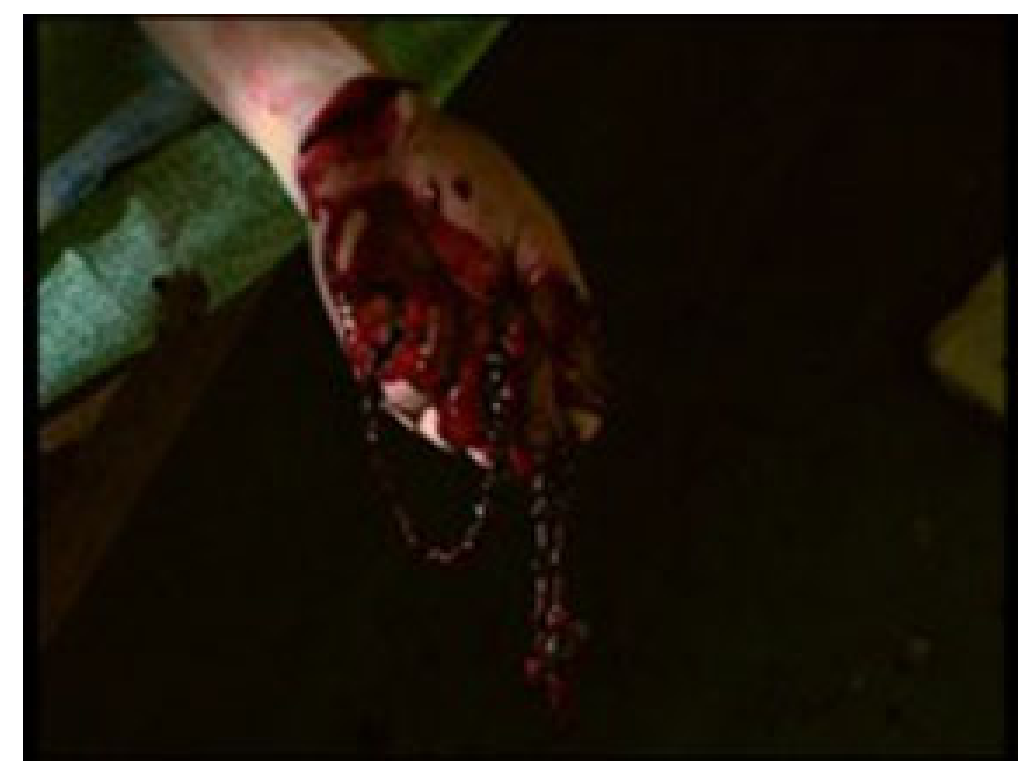

Figure 5: Fig. 4. Religious icons in Dead Meat

It is within this context that Dead Meat reimagines one of the most emotive of nationalist motifs - the 
hurley stick or camán - as one of the weapons of choice for those few survivors in their attempts to escape their zombie pursuers. Indeed, the production was initially to include a hurling match with a zombie pitch invasion, but this proved to be logistically impossible within the microbudget (the film was the first to be produced under the Irish Film Board's microbudget initiative) ${ }^{(15)}$ parameters of the production. Such was the impact of the hurley stick's use in an early screen test that McMahon has recalled one spectator remarking on 'the hurley [as] the new chainsaw', quite possibly referring to one moment in particular in the film in which the hurling coach almost decapitates a zombie - who appears to have been a bride-to-be before her transformation - with the assistance of a hurley stick, from the jeep in which the tourist Elena and gravedigger Desmond are also fleeing the zombies (figure 6).

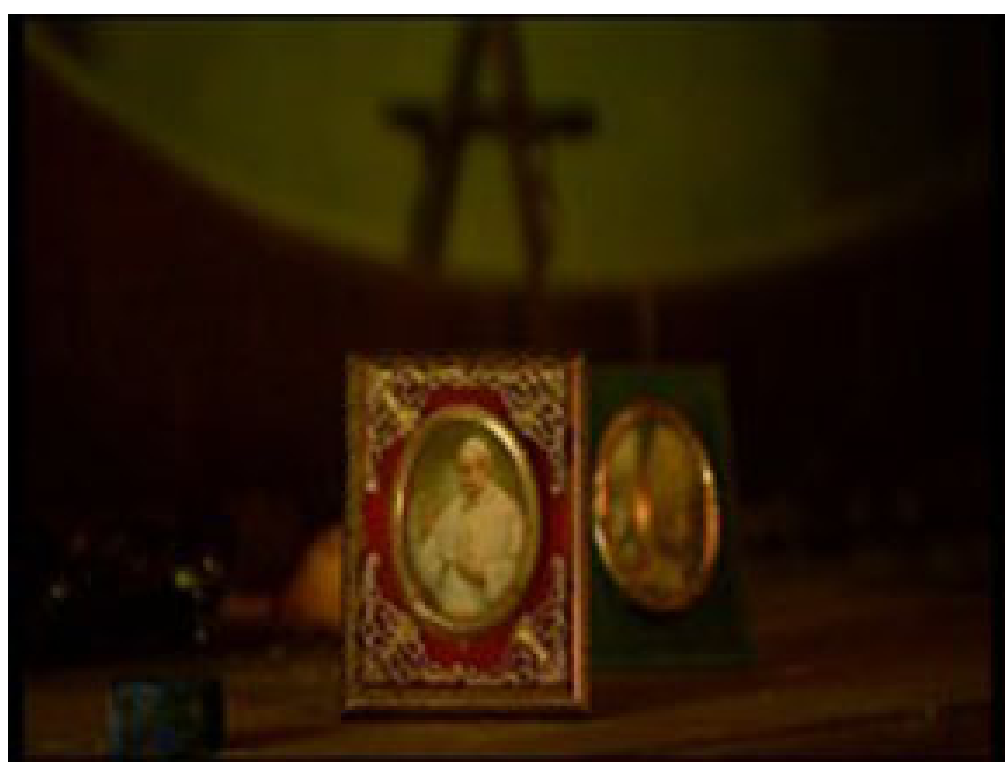

Figure 6: Fig. 5. Religious icons in Dead Meat

While the use of the hurley stick here as a weapon may superficially seem to perpetuate a stereotype familiar from international representations of the sport in earlier periods, in common with the distinctive Irish accents throughout the film, McMahon's choice of the hurley stick further localizes a prominent aspect of the horror film historically - namely the weapons commonly featured such as a knife or a chainsaw - with a distinctive aspect of Irish culture. Furthermore, elsewhere in the film the presence of the hurley stick is nuanced by its evocation of a mythological precursor in the figure of Cúchulainn, and its connection with local and immediate political developments which may well be part of a larger critique of political failures in a time of plenty. This is also represented in the neglect and decline of rural Ireland itself as depicted throughout the film, the promotion of unethical farming practices, and the evocative figure of the zombie.

Indeed, the figure of the zombie provides a highly suggestive motif for a film made at the height of the Celtic Tiger. From George Romero's reimagining of the zombie figure in Night of the living Dead (1968), zombie films have been centrally concerned with social criticism. This criticism in Dead Meat is most explicitly made of intensive farming practices themselves. Here the explanation offered for the infection of humans and their transformation into zombies is the spread of a particularly virulent strain of BSE or Mad Cow Disease from animals to humans, following the feeding of livestock with food acquired from the carcasses of dead animals. McMahon is here referring to the practice identified by scientists as responsible for the spread of BSE, but there is a wider critique apparent of the modern capitalist means of food production in the west. As Felicity Lawrence has noted in her recent study Eat your Heart Out: Why the Food Business is Bad for the Planel and Your health:

Modern food production involves processes that, quite apart from having little care for real nutrition, drive people off the land, stimulate migration, increase inequalities and the depth of poverty, are corrosive of society, and depend on extravagant use of natural resources, from water 
to oil to land, that are running out. The politics of food is in other words not the art of shopping but the politics of modern globalised capitalism itself. ${ }^{(16)}$

Indeed, while the horror genre in the 1950s has been associated with a fear of communist infiltration evident in films such as The Thing (Christian Nyby, 1951) and Them! (Gordon Douglas, 1954) (Wood, 1985: 210), the zombie itself has latterly been interpreted as a recurring symbol in film of the evils of capitalism. As Robin Wood notes cannibalism 'represents the ultimate in possessiveness, hence the logical end of human relations under capitalism' (Wood, 1985: 213) a point developed in his subsequent study Hollywood from Vietnam to Reagan where he argues that zombies 'represent on a metaphorical level, the whole dead weight of patriarchal consumer capitalism, from whose habits of behaviour and desire not even Hare Krishnas and nuns....are exempt' (Wood, 1986: 118). Given the context within which Dead Meat was made and released, a Celtic Tiger Ireland marked by often ostentatious wealth and high consumerist spending encouraged by neo-liberalist economic policies of successive Fianna Fáil-led governments and reflected today in a time of recession in one of the highest levels of personal debt in Europe, ${ }^{(17)}$

McMahon could hardly have chosen a more appropriate time to employ such a resonant motif. Indeed, at a time when the continuing Celtic Tiger economy was dependent primarily on unbridled consumption that fed a property bubble the collapse of which has been at the centre of subsequent economic decline, McMahon depicts a world in which human life itself has become so devalued that human beings have become consumable. And if the criticism was not clear enough, the director offered a further significant piece of dialogue in an evocative scene in which we witness the hurling coach, Cathal Cheunt, defend the few uninfected survivors from an attacking Mad Cow, in the style of Cúchulainn, with his hurling stick and sliotar. We hear a repetition of the campaigning slogan - 'A lot done, more to do' - used by Fianna Fáil, and particularly associated with the party's then leader Bertie Aherne, prior to the 2002 election which returned the party to power (figure 7). The local significance of this statement's inclusion has been commented on by McMahon himself who remarked 'That's a line only Irish people will probably get...that was the Taoiseach's slogan' while the film's producer Ed King has described the line as possibly a better tag line for the movie as a whole than that chosen on its release. ${ }^{(18)}$

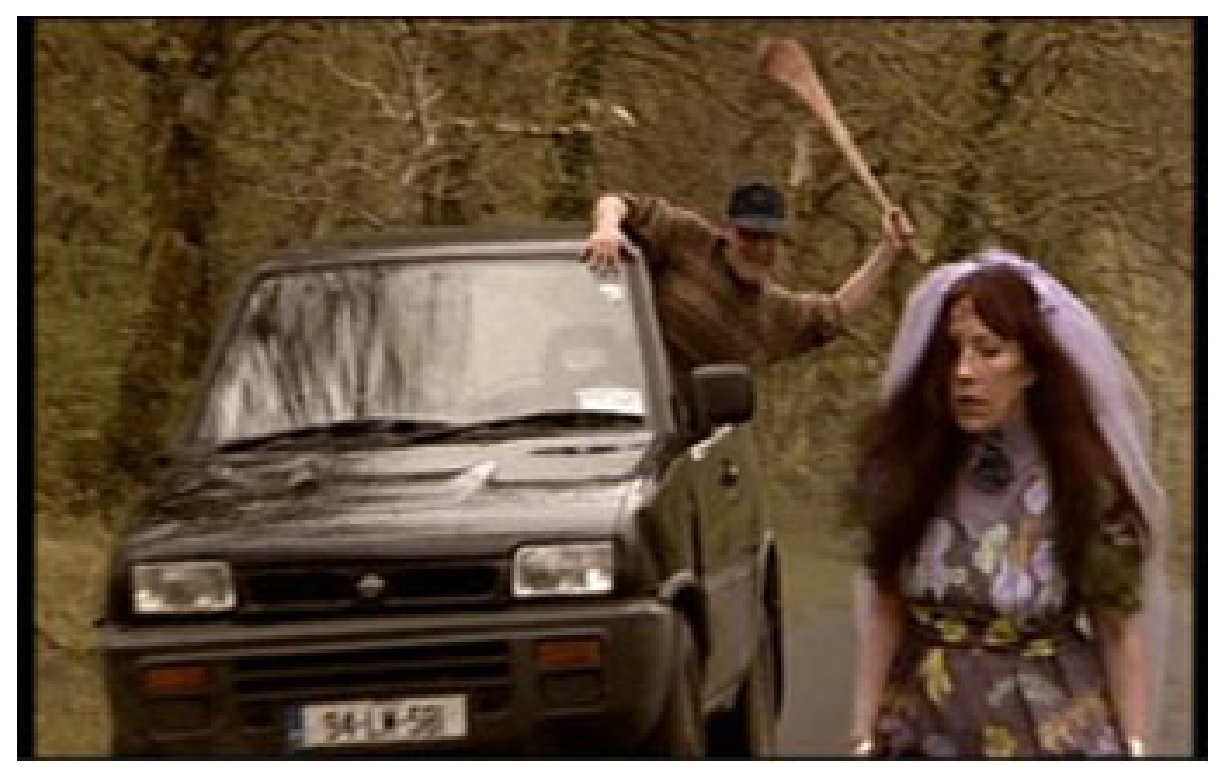

Figure 7: Fig. 6. The hurling coach about to attack a zombie with his camán in Dead Meat

To conclude, though Celtic Tiger cinema may sometimes have offered a bright and positive portrayal of Ireland, the latter days of the Celtic Tiger saw the emergence of the horror genre as a recurring form adopted by Irish directors. It revealed not a bright depiction of boomtime Ireland, but rather a dark and dystopian nightmare, often focused on the rural space. It is a rural Ireland far removed from either nationalist mythology or the tourist gaze. Indeed, much as the tourist gaze has been associated with a particular vision 
of Ireland, epitomized in the representation of the indigenous sport of hurling as both rural, backward and potentially violent, a contemporary film such as Dead Meat, in common with other recent horror films including Paddy Breatnach's Shrooms may well constitute a counter-touristic vision, one in which hurling functions as a protective motif against the onslaught of voracious global capitalism. While international productions featuring Gaelic games have revealed the influence of the tourist gaze, it is the local gaze McMahon ultimately invites through his critical engagement with contemporary Irish politics and society and his playful and satiric evocation of mythological precedents and previous stereotypical representations. Indeed, it is this exaggerated performative play with stereotypes which ultimately satirises earlier depictions to produce a representation of both Ireland and Irish sport far removed from that of previous tourist-inflected productions.

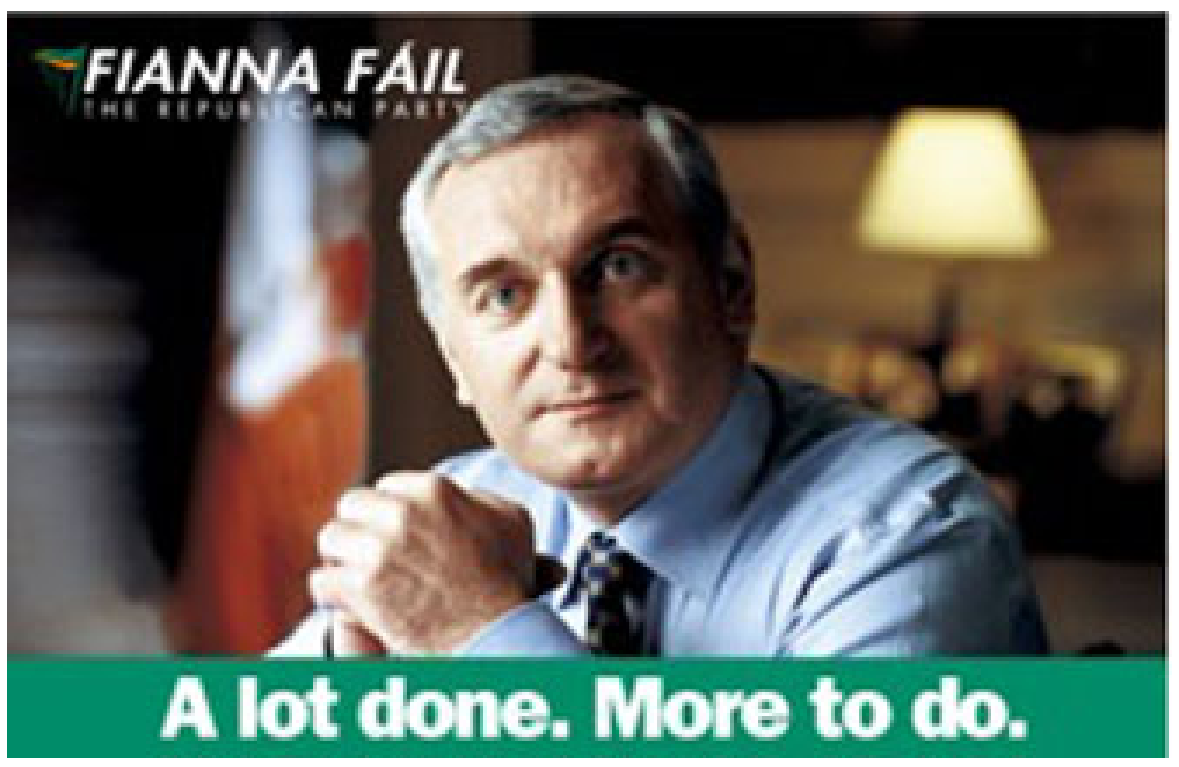

Figure 8: Fig. 7. 2002 Election Campaign poster for Fianna Fáil

\section{Notes}

1. This photograph of graffiti in Dublin's Ranelagh district was printed in the Irish edition of The Star, Tuesday $16^{\text {th }}$ June, 2009: 8 .

2. Indeed, on Sunday August $2^{\text {nd }} 2009$, The Sunday Times's Irish edition reported that Aherne had been forced to drop "a lecture titled The Celtic Tiger: the Irish Model of Development from his portfolio of afterdinner speeches" presumably due to the dramatic decline in the country's fortunes. [Colin Doyle, "Bertie Ahern told to drop the Tiger", The Sunday Times [Irish Edition], $2^{\text {nd }}$ August, 2009: 3.]

3. Dáil Éireann - Volume 374 - 28 October, 1987. Ceisteanna - Questions. Oral Answers. - Film Industry. Available at http://www.oireachtas-debates.gov.ie (accessed November 22 2009)

4. For more on this festival see "Horrorthon Film Festival" at

http://www.melies.org/festival.asp?ID=33 and Niall Kitson, "A Horror Unto Itself", Film Ireland [Web Exclusives], Saturday, February 14, 2009,

http://www.filmireland.net/exclusives/horrorthon2008.htm. Accessed November 10th 2009.

5. The horror genre of course is not an entirely new development in Irish culture. Indeed, Irish motifs, from the banshee to the leprechaun, have provided recurring figures of fear in international, and particularly American cinema. Arguably the most enduring figure of terror in film over the past 100 years, the vampire, owes its origins, in literature at least, to the late 19th century Irish author Bram Stoker's novel Dracula. Irish 
narratives, locales, superstitions and the figures that occupy them therefore have been recurring features of horror cinema internationally.

6. McMahon is currently working on a further horror/slasher film with the working title of The Clown.

7. For a discussion of these influences see "The Butcher", "A wonderful Sam Saimi Irishinspired zombie fest", killerreviews.com

http://www.killerreviews.com/staff_review.php?movieid=2528. Accessed July 22nd 2009. See also Wayne Simmons, "Interview with Conor McMahon", Zombie-A-GoGo Interviews, Wednesday, February 15, 2006, http://zagginterviews.blogspot.com/2006/02/conor-mcmahon.html. (Accessed July 27th 2008) for McMahon's own comments on the film's homages to previous horror films.

8. For more on this see Seán Crosson, "Gaelic Games and 'the Movies'", The Gaelic Athletic Association 1884-2009, ed. Mike Cronin, William Murphy and Paul Rouse (Dublin: Irish Academic Press, 2009) 111-136.

9. Indeed, this view was encouraged by the Gaelic Athletic Association itself in its frequent assertion of hurling's antiquity.

10. While both The Quiet Man and The Rising of the Moon are mentioned above, another example of the juxtaposition of hurling and violence is also found in Ford and Jack Cardiff's Young Cassidy (1965).

11. For further on this film and its importance to the development of tourism in Ireland, see Seán Crosson and Rod Stoneman, The Quiet Man ... and Beyond: Reflections on a Classic Film, John Ford and Ireland (Dublin: Liffey Press, 2009).

12. One of the most famous episodes associated with Cúchulainn involves him defending himself from an attacking hound with his hurling stick and sliotar, the ball used in the game.

13. Ibid.

14. See "The Butcher", "A wonderful Sam Saimi Irish inspired zombie fest", killerreviews.com, http://www.killerreviews.com/staff_review.php?movieid=2528.

Accessed July 22nd 2000. Also Wayne Simmons, "Interview with Conor McMahon", Zombie-A-GoGo Interviews, Wednesday, February 15, 2006,

http://zagginterviews.blogspot.com/2006/02/conor-mcmahon.html. Accessed July 27th 2009.

15. In the "making-of" documentary, Mad Cows and Zombies, included on the DVD release of Dead Meat, Brendan McCarthy, who was then Head of Production and Development at the Irish Film Board and who was concerned that horror was a neglected genre in Irish film, describes Dead Meat as the first micro-budget film funded by the board as well as the first horror film the board was involved with.

16. Quoted in Alexander Cockburn, "A Bitter harvest", The Sunday Times, Culture, July 13 2008: 40.

17. As Fintan O'Toole noted in 2007, "National debt as a percentage of GDP fell from 87.7 per cent in 1990 to 20.4 per cent in 2006. But lending by credit institutions to private households has more than trebled from $€ 39$ billion in 2000 to $€ 134$ billion in 2006. Outstanding indebtedness on credit cards stood at $€ 1.5$ billion at the end of 2002 . At the end of 2006, it was €2.7 billion. Ireland has acquired the highest ratio of personal debt to GNP in the euro zone." [Fintan O'Toole, "Fruit of the boom years squandered", The Irish Times, Tuesday, November 20, 2007

http://www.irishtimes.com/newspaper/opinion/2007/1120/1195251510571.html. Accessed June 27th 2009]. See also Paul Cullen, "Household debt up due to mortgage borrowing", The Irish Times, Thursday, April 30,2009

http://www.irishtimes.com/newspaper/ireland/2009/0430/1224245682024.html. Accessed January 5th 2010.

18. Both of these comments are taken from the director's commentary to the DVD release of Dead Meat. 


\section{References}

\section{References}

Anonymous, 2006. "Interview with Conor McMahon", killerreviews.com,

http://www.killerreviews.com/interview_dead_meat.asp. Accessed 27th May 2008.

Barton, Ruth, 2004. Irish National Cinema. London: Routledge.

Barton, Ruth, 2006. "Boy Eats Girl (2006)", Estudios Irlandeses, 1, 162-163.

Black, Cathal, 1996. "Cathal Black interview with Vincent Browne", Film West 24 (Spring), 22- 24.

Gibbons, Luke, 2002. The Quiet Man.Cork: Cork University Press.

Kawin, Bruce, 1999. "The Mummy's Pool". In: Leo Braudy and Marshall Cohen (eds.) Film Theory and Criticism: Introductory Readings. Oxford: Oxford University Press.

Lowenstein, Adam, 2005. Shocking representation: Historical Trauma, National Cinema and the Modern Horror Film. New York: Columbia University Press.

McBride, Joseph, 2001. Searching for John Ford: a life. New York: St. Martin's Press.

McCarthy et al, Colm, 2009. Report of the Special Group on Public Service Numbers and Expenditure Programmes. Volume II: Detailed Papers. Dublin: Government Publications Sales Office.

Monahan, Barry, 2007. "Attack of the Killer Cows! Reading Genre and Context in Isolation (2005)" Estudios Irlandeses, 2, 264-266.

Nichols, Bill, 1985.

O'Neill, Anthony, 1999. "A certain tendency of the Irish cinema", Film West 36, 16-17.

Rockett, Kevin, Luke Gibbons, and John Hill, 1988. Cinema and Ireland. London and New York: Routledge.

Simmons, Wayne, 2006. "Interview with Conor McMahon", Zombie-A-GoGo Interviews, Wednesday, $15^{\text {th }}$ February 2006.

http://zagginterviews.blogspot.com/2006/02/conor-mcmahon.html. Accessed July 27th 2008.

Urry, John, 2001. The Tourist Gaze. London, Sage.

Wood, Robin, 1985. "An Introduction to the American Horror Film". In: Bill Nichols (ed.) Movies and methods Volume II Berkeley: University of California Press, pp. 195-219.

Wood, Robin, 1986. Hollywood from Vietnam to Reagan New York: Columbia University Press.

\section{Author Information}

Seán CROSSON is programme director of the MA in Film Studies: Theory and Practice with the Huston School of Film \& Digital Media in NUI Galway. Dr. Crosson's research interests include Irish film, film and sport, and the relationship between music and poetry. He is the author of a study of the sports film genre, Sport and Film (Routledge, 2013). 